\section{Lovorka Magaš Bilandžić}

Filozofski fakultet Sveučilišta u Zagrebu, Odsjek za povijest umjetnosti / Faculty of Humanities and Social Sciences, University of Zagreb, Department of Art History Ivana Lučića 3, Zagreb

lmagas@ffzg.hr

Izvorni znanstveni rad / Original scientific paper UDK / UDC: 76 Glumac, S.

659.12:[664.31(497.5 Zagreb)"193"

DOI: $10.17685 /$ Peristil.59.9

30. 8. 2016.

\title{
Sergije Glumac i vizualni identitet Prve hrvatske tvornice ulja u 1930-ima
}

Ključne riječi: grafički dizajn, reklama, Sergije Glumac, Prva hrvatska tvornica ulja, zagrebačko ulje Crvena zvijezda, obitelj Aleksander, prehrambena industrija, međuratno razdoblje

Keywords: graphic design, advertising, Sergije Glumac, First Croatian Oil Factory, Zagreb Red Star Oil, the Aleksander family, food industry, interwar period

U članku se na osnovi arhivske dokumentacije, sačuvanih skica, plakata i ostale građe analizira razgranata i intenzivna suradnja grafičkog dizajnera Sergija Glumca s Prvom hrvatskom tvornicom ulja. Razmatra se Glumčeva značajna uloga u koordiniranju cjelokupne propagandne djelatnosti tvornice i oblikovanju njezina modernoga vizualnog identiteta te doprinos oglašavanju prehrambene industrije u Hrvatskoj tijekom međuratnog razdoblja.

Tijekom međuratnog razdoblja hrvatski grafičar, grafički dizajner i scenograf Sergije Glumac (1903.-1964.) surađivao je s brojnim kulturnim, društvenim i gospodarskim institucijama (Narodno kazalište, Zagrebački zbor itd.) te tvrtkama i tvornicama koje su se nalazile u privatnom vlasništvu. Značajno mjesto u njegovu bogatom grafičko-dizajnerskom opusu zauzima rad na oglašavanju prehrambene industrije i oblikovanju prepoznatljivoga vizualnog identiteta Prve hrvatske tvornice ulja d. d. i njezinih proizvoda, o čemu do sada nije pisano u povijesti hrvatskoga grafičkog dizajna. ${ }^{1}$

Prva hrvatska tvornica ulja nalazila se u vlasništvu istaknute zagrebačke židovske obitelji Aleksander (Alexander) s kojom je Glumac bio privatno i profesionalno povezan. Tijekom 1930-ih radio je kao grafički dizajner za tvrtke u posjedu Aleksanderovih i bio zadužen za oblikovanje vizualnog identiteta i koordiniranje cjelokupne propagandne aktivnosti Prve hrvatske tvornice ulja: od plasiranja proizvoda na tržište putem opsežnog oglašavanja do organizacije njezina prezentiranja na značajnim gospodarskim sajmovima poput Zagrebačkog zbora i Ljubljanskog velesajma. ${ }^{2}$ $\mathrm{U}$ radu se na osnovi arhivske građe i korespondencije, te neobjavljenih skica, realiziranih plakata i ostalih reklamnih materijala, rekonstruira Glumčeva uloga u kreiranju modernog imagea Prve hrvatske tvornice ulja i njegov doprinos implementiranju novih standarda u grafičkom oblikovanju namijenjenom oglašavanju prehrambene industrije (sl. 1). Posebna pozornost posvećena je načinu na koji je tvornica progresivnom reklamnom djelatnošću i atraktivnim grafičkim dizajnom nastojala stvoriti nove navike kod potrošača i pojačati korištenje ulja u svakodnevnom životu te zauzeti vodeće mjesto u odnosu na strane distributere u proizvodnji i trgovini uljem na tržištu Hrvatske i Kraljevine Jugoslavije.

\section{Obitelj Aleksander i Prva hrvatska tvornica ulja}

Dioničarsko društvo Prva hrvatska tvornica ulja, preteča današnje Zvijezde d. d., osnovano je prije sto godina u jeku Prvoga svjetskog rata (15. rujna 1916.) ${ }^{3}$ s ciljem izgradnje tvorničkog kompleksa te eksploatacije i prodaje različitih vrsta uljarica. Njome su upravljali dioničari tvornice, istaknuti privrednici i intelektualci braća Samuel David 


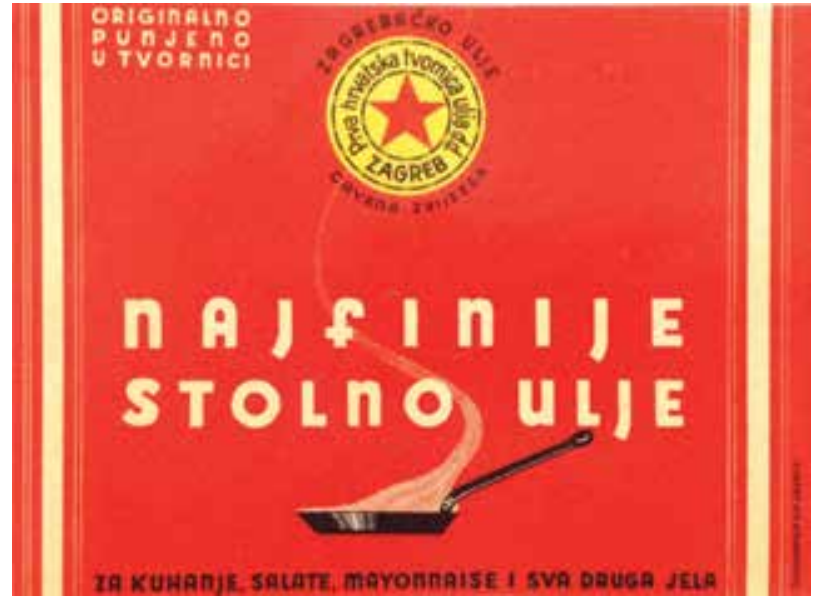

1. Sergije Glumac, Najfinije stolno ulje, etiketa, 1934. (Grafička zbirka Nacionalne i sveučilišne knjižnice, Zagreb) / Sergije Glumac, Finest Cooking Oil, label, 1934 (Print Collection of the National and University Library, Zagreb)

i Šandor A. Aleksander, tadašnji predsjednik Trgovačke i obrtničke komore arhitekt Vjekoslav Heinzel, ravnatelj Hrvatske eskomptne banke ekonomist Stanko Šverljuga i trgovac iz Graza Alfred Pick koji je imao iskustva u proizvodnji ulja. ${ }^{4}$ Većinski vlasnici dionica bila su braća Samuel i Šandor Aleksander, a tvornica je funkcionirala kao »tipično obiteljsko poduzeće«..$^{5}$

Obitelj Aleksander imala je značajnu ulogu u društvenom, gospodarskom, kulturnom i političkom životu Hrvatske do početka Drugoga svjetskog rata. Članovi obitelji utjecali su na modernizaciju mnogih aspekata gospodarskog života, agilno sudjelovali u različitim udruženjima, aktivno politički i humanitarno djelovali te posjedovali tvornice kojima su unaprijedili onodobnu prehrambenu, kemijsku, građevinsku i rudarsku industriju. Samuel D. Aleksander školovao se na Trgovačkoj akademiji u Grazu, a u prvim desetljećima 20. stoljeća posjedovao je i upravljao nizom tvornica (Zagrebačkom dioničkom pivovarom i tvornicom slada, Mirna ugljenokopnim d. d. itd.) te sudjelovao u osnivanju Zagrebačke burze i Zagrebačkog zbora. ${ }^{6}$ Njegov mlađi brat Šandor A. Aleksander obnašao je različite istaknute političke i upravljačke funkcije (gradskog zastupnika, predsjednika trgovačkog društva Merkur itd.), a posebno mjesto u kolektivnoj memoriji osigurao je karitativnim djelovanjem svojega dobrotvornog društva Prehrana koje je od Prvoga svjetskog rata pomagalo siromašne građane i najpotrebitije.

Aleksanderovi su bili uspješni poduzetnici dobro upoznati s potrebama lokalnog tržišta te su prepoznali potencijal pokretanja tvornice specijalizirane za proizvodnju ulja s obzirom na to »da je zbog rata bilo sve manje jestivih masti a da je u Hrvatskoj bilo neiskorištenih uljarica«. Tvornica je započela s radom 1917. i bila smještena uz željezničku prugu na tadašnjoj gradskoj periferiji (današnja Branimirova ulica), a bavila se prerađivanjem različitih sirovina: prvo bundevskih koštica, a poslije uljane repice, suncokreta, soje itd. Tijekom međuratnog razdoblja tvornica je bilježila progresivan rast: unatoč povremenim krizama uzrokovanim jačanjem konkurencije, reperkusijama ekonomske krize, povećanjem proizvodnje svinjske masti i padanjem cijena ulja, ostvarivala je značajnu participaciju u ukupnoj proizvodnji uljarske industrije u Jugoslaviji (oko 50-55\%). ${ }^{8}$

Članovi obitelji Aleksander tijekom međuratnog razdoblja značajnu su pozornost posvećivali reklamnom djelovanju i pažljivom osmišljavaju branda tvornica koje su se nalazile u njihovu vlasništvu (Zagrebačke dioničke pivovare i tvornice slada, Prve hrvatske tvornice ulja) i popularnih proizvoda svakodnevne potrošnje koje su plasirali na široko tržište Kraljevine SHS/Jugoslavije. Za razliku od mnogih onodobnih privrednika koji još uvijek nisu shvaćali koliko stručno osmišljena i vizualno dojmljiva reklama može biti produktivna, Aleksanderovi su razumjeli važnu ulogu oglašavanja u prezentiranju proizvoda, osvajanju tržišta i kreiranju novih navika potrošača te za svoje reklamne akcije angažirali stručnjake.

\section{Suradnja Sergija Glumca s Prvom hrvatskom tvornicom ulja}

Sergije Glumac poslovnu je suradnju s obitelji Aleksander započeo u drugoj polovini 1920-ih, nakon završetka »škole za kandidate učiteljstva crtanja na srednjim školama" na Kraljevskoj akademiji za umjetnost i umjetni obrt (1927.) i boravka u Parizu gdje je 1927./28. samostalno radio i pohađao predavanja na Sorbonnei. ${ }^{9}$ Po povratku u Zagreb dvadesetpetogodišnji Glumac s nekoliko je umjetnika i reklamnim stručnjakom Miroslavom Fellerom pokrenuo Zavod za znanstveno proučavanje reklame i umjetničku reklamnu produkciju Imago koji je kratko djelovao 1928./29. Imago je imao značajnu ulogu u profesionalizaciji reklamnog poslovanja u Hrvatskoj i implementiranju visokih standarda u koncepciji i grafičkom oblikovanju novinskih oglasa, plakata i kampanja te je promicao stvaranje modernih i funkcionalnih reklama koje su se temeljile na znanstvenim i praktičnim spoznajama o uspješnom tržišnom komuniciranju. ${ }^{10}$ Glumac je već tijekom rada u zavodu Imago počeo surađivati s tvornicama koje su se nalazile u vlasništvu obitelji Aleksander: u sklopu zavoda 1929. oblikovao je plakat i reklamnu kampanju za popularno bezalkoholno piće Skaut koje je proizvodila Zagrebačka dionička pivovara i tvornica slada. ${ }^{11}$ Do suradnje zavoda Imago s pivovarom najvjerojatnije je došlo upravo posredovanjem Glumca koji je još od školskih dana bio prijateljski povezan s Draguti- 
nom i Brankom Aleksanderom, sinovima Samuela Davida. Glumac je braću Aleksander upoznao tijekom školovanja na Kraljevskoj I. realnoj muškoj gimnaziji u Klaićevoj ulici koju je kao eksternist upisao u studenome 1920. nakon dolaska u Zagreb iz Beograda, ${ }^{12}$ a prijateljska je veza s vremenom prerasla i u obiteljsku. Naime, Dragutin i Branko Aleksander bili su bratići Zore pl. Aleksander, kćeri jedinice Šandora A. Aleksandera te majke Glumčeve buduće supruge Blanke Ausch (Auš) Marić. Obojica su, kao i njihova braća Ivo i Božidar (druga dva sina Samuela Davida), imala važnu ulogu u obiteljskom poslovnom carstvu, a nakon realke obrazovali su se na poznatim europskim sveučilištima kako bi mogli preuzeti pojedine istaknute funkcije u vodstvu očevih tvrtki. Branko Aleksander studirao je ekonomiju u Baselu i preuzeo upravljanje Prvom hrvatskom tvornicom ulja, a Dragutin Aleksander u Njemačkoj se školovao za inženjera rudarstva te usmjerio na ugljenokop Mirna. ${ }^{13}$

Glumac je tijekom 1930-ih intenzivno surađivao s tvornicama i tvrtkama koje su bile u vlasništvu Aleksanderovih (Zagrebačka dionička pivovara i tvornica slada, Prva hrvatska tvornica ulja), ali i supruga Zore pl. Aleksander Artura Marića i njegova brata Milana (Anglo-jugoslavensko petrolejsko d. d. / Shell, Hinko Mayer i drug itd.). Za pripadnike obitelji Aleksander i Marić također je projektirao moderno uređene interijere i pojedine dijelove namještaja, izrađivao ex librise i prigodne novogodišnje čestitke, a oni su od njega otkupljivali umjetničke radove. ${ }^{14}$

Glumac je godinama koordinirao propagandne aktivnosti Prve hrvatske tvornice ulja. Za tvornicu je obavljao širok dijapazon djelatnosti - od grafičkog oblikovanja reklamnih materijala i kreiranja prepoznatljivoga vizualnog identiteta do komunikacije s različitim tiskarama i reklamnim agencijama (Jugoreklam, Publicitas, Tipografija, Zaklada tiskare Narodnih novina itd.) te stručnjacima od kojih su naručivani prijedlozi reklamnih akcija. ${ }^{15}$ Tijekom 1930-ih za pojedine poslove u prezentaciji tvornice (dekoraciju, prijevod) povremeno je angažirao i kolege iz zagrebačkoga Narodnog kazališta s kojim je u tom razdoblju surađivao kao scenograf. ${ }^{16}$

\section{Oglašavanje prehrambene industrije $\mathrm{i}$ industrije ulja u Kraljevini Jugoslaviji u međuratnom razdoblju}

Međuratno razdoblje u Kraljevini SHS/Jugoslaviji bilo je obilježeno turbulentnim političkim životom i reperkusijama svjetske ekonomske krize, ali i jačanjem tržišta i potražnjom za robom svakodnevne potrošnje te povećanjem kupovne moći stanovništva. Takva situacija pogodovala je sustavnom razvoju tržišnih komunikacija »jer potreba za cjelovitim izvješćivanjem javnosti o tržišnoj ponudi tolika je da se konkurentnim moglo ostati jedino ulaganjem u reklamu «. ${ }^{17}$ Oglašavanje prehrambene industrije u Hrvatskoj postupno se razvijalo tijekom međuratnog razdoblja, a bilo je svedeno na nekoliko uobičajenih formula: a) koristili su se gotovi grafički obrasci uvezeni iz inozemstva koji su bili prilagođeni lokalnom tržištu prevođenjem natpisa na hrvatski jezik; b) upotrebljavali su se narativni realistički prikazi ili jednostavni tipografski oglasi koji su povremeno dinamizirani poigravanjem tipom i veličinom slova; c) primjenjivala su se autorska rješenja obilježena korištenjem suvremenoga vizualnog vokabulara i stvaranjem modernih, funkcionalnih reklama.

Među različitim granama prehrambene industrije ${ }^{18}$ tijekom prvih desetljeća 20. stoljeća najveći broj kvalitetnih grafičkih i autorskih rješenja u oblikovanju reklama pojedinačnih proizvođača i artikala manifestirao se $u$ industriji pića, kave i duhana. U razdoblju između dva svjetska rata oglasi vodećih grafičkih dizajnera poput Pavla Gavranića i Sergija Glumca ispunjavali su stranice dnevnih tiskovina i periodičkih publikacija (npr. Svijeta), a oba autora istaknula su se oblikovanjem plakata i kampanja za poznate tvornice pića i pivovare: Gavranić za Pokorny, a Glumac za Zagrebačku dioničku pivovaru i tvornicu slada. Obje su tvornice od početka 20. stoljeća intenzivno investirale u vlastitu propagandu i značajnu su pozornost posvećivale vizualnom prezentiranju proizvoda, njihovu plasmanu na širokom tržištu i među različitim društvenim slojevima, a plakate su naručivali od istaknutih umjetnika poput Tomislava Krizmana (Pokorny) ili Mencija Clementa Crnčića (Zagrebačka dionička pivovara). ${ }^{19}$ Glumac i Gavranić u oblikovanju reklama za Pokorny i Zagrebačku dioničku pivovaru i tvornicu slada reinterpretirali su uspostavljene obrasce svojih prethodnika te primjenjivali različite postupke - od stvaranja prepoznatljive ikone koja preuzima ulogu agenta koji oglašava popularni liker Pokorny (Gavranić) ${ }^{20}$ do primjene širokog dijapazona rješenja (Glumac). Glumac se na tipografskim plakatima za pivo Tomislav poigravao $s$ konotativnim značenjima pojedinih ukrasnih pisama, dok je prikazivanjem potencijalnih konzumenata na rješenjima za bezalkoholno piće Skaut apelirao na identifikaciju ciljanih potrošača ${ }^{21}(\mathrm{sl} .2 \mathrm{ab})$.

Zahvaljujući razvoju domaće industrije ulja tijekom međuratnog razdoblja dolazi do emancipacije od uvoza inozemnih proizvoda. ${ }^{22}$ Nastoji se educirati potrošače i promijeniti njihove navike kako bi umjesto inozemnih odabrali ulje domaćih proizvođača čija kvaliteta nije zaostajala za stranim markama. Iako je propagandna djelatnost imala potencijalno značajnu ulogu u generiranju novih potreba, $u$ oglašavanju različitih ulja koja su bila dostupna na lokalnom tržištu dominirala su denotativna rješenja koja su donosila opće informacije o nazivu, upotrebi, cijeni, pakiranju i 


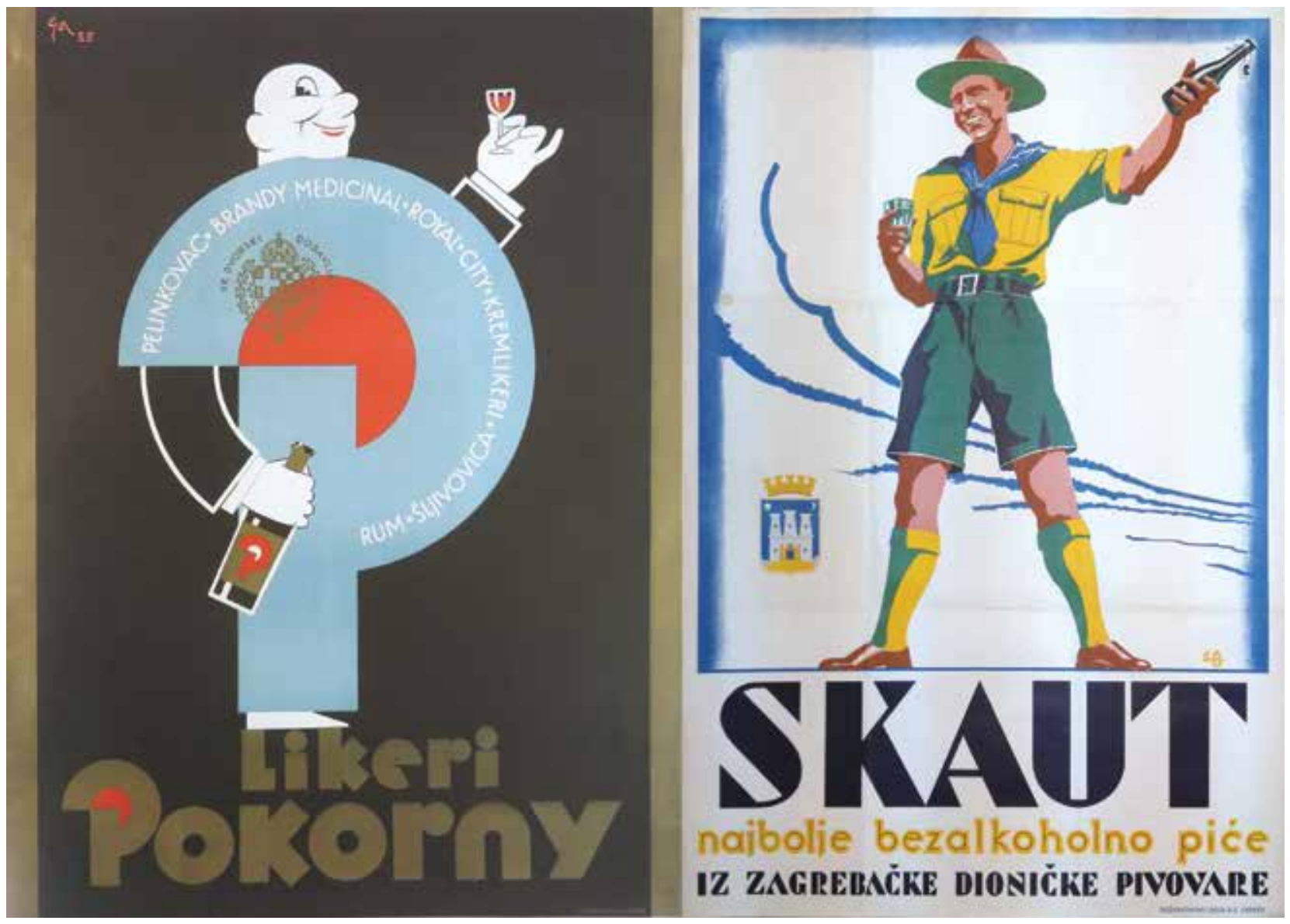

2a. Pavao Gavranić, Likeri Pokorny, 1935. (Kabinet grafike HAZU, Zagreb); 2b. Sergije Glumac, Skaut - najbolje bezalkoholno piće, 1929. (Kabinet grafike HAZU, Zagreb) / 2a. Pavao Gavranić, Pokorny Liquors, 1935 (Department of Prints and Drawings of the Croatian Academy of Sciences and Arts, Zagreb); 2b. Sergije Glumac, Skaut - Best Non-alcoholic Beverage, 1929 (Department of Prints and Drawings of the Croatian Academy of Sciences and Arts, Zagreb)

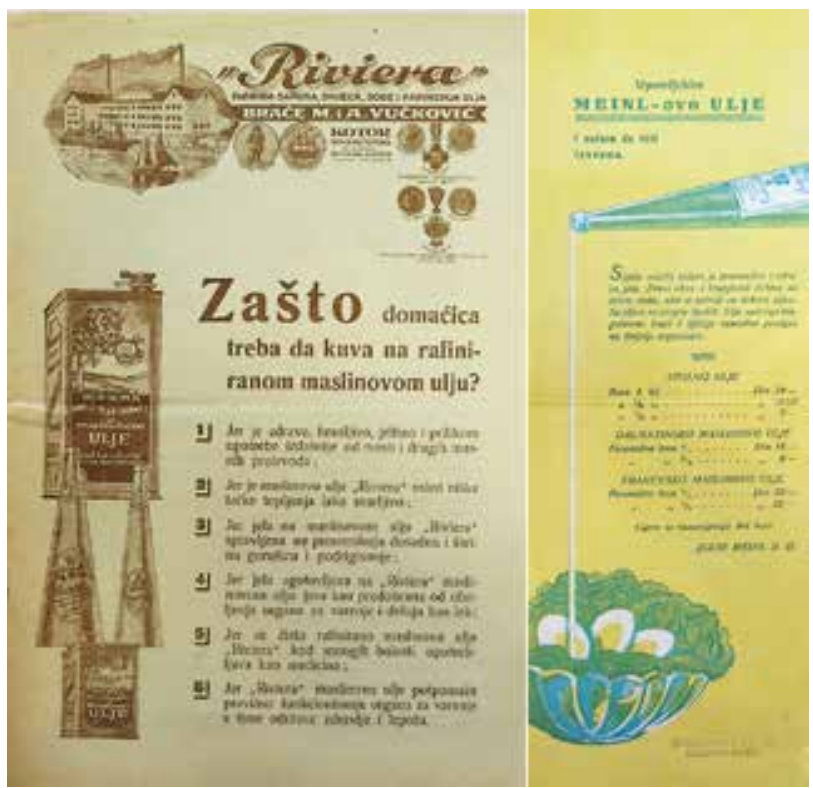

3. Promotivni letci za ulja Riviera i Meinl, 1920-e/1930-e (Grafička zbirka Nacionalne i sveučilišne knjižnice, Zagreb) / Promotional leaflets for Riviera and Meinl oils, 1920s/1930s (Print Collection of the National and University Library, Zagreb) mjestu gdje se proizvod može nabaviti. O tome svjedoče sačuvani reklamni materijali dalmatinskih maslinovih ulja Dubravka i Riviera koja su oglašavana anakronističkim i tradicionalno oblikovanim letcima i brošurama u kojima je dominirao tekst s opisanim prednostima odabranog ulja popraćen vizualnim materijalom koji je asocirao na podneblje ili prikazivao proizvod. ${ }^{23}$ Istodobno su reklamni materijali (letci, upute o pripremi jela itd.) inozemnih dobavljača poput tvrtke Julio Meinl kombinirali tekst i realistički crtež te koristili uobičajene formule u oglašavanju ulja (prikaze ulja i salate, trenutka začinjanja hrane ili domaćica/kuharica kako izlijevaju ulje na tavu ${ }^{24}($ sl. 3).

Rješenja Sergija Glumca za plakate, oglase i publikacije Prve hrvatske tvornice ulja i njezina glavnog proizvoda zagrebačkog ulja Crvena zvijezda (ujedno i zaštitnog znaka tvrtke) ${ }^{25}$ - zanimljiva su u kontekstu onodobne produkcije na nekoliko razina, a od reklama konkurentskih dobavljača poput Meinla ili privatnih dalmatinskih uljara razlikovala su se po modernosti i čistoći vizualnog govora, verbalnom strukturiranju poruke i konstruiranju konotativnih značenja. 


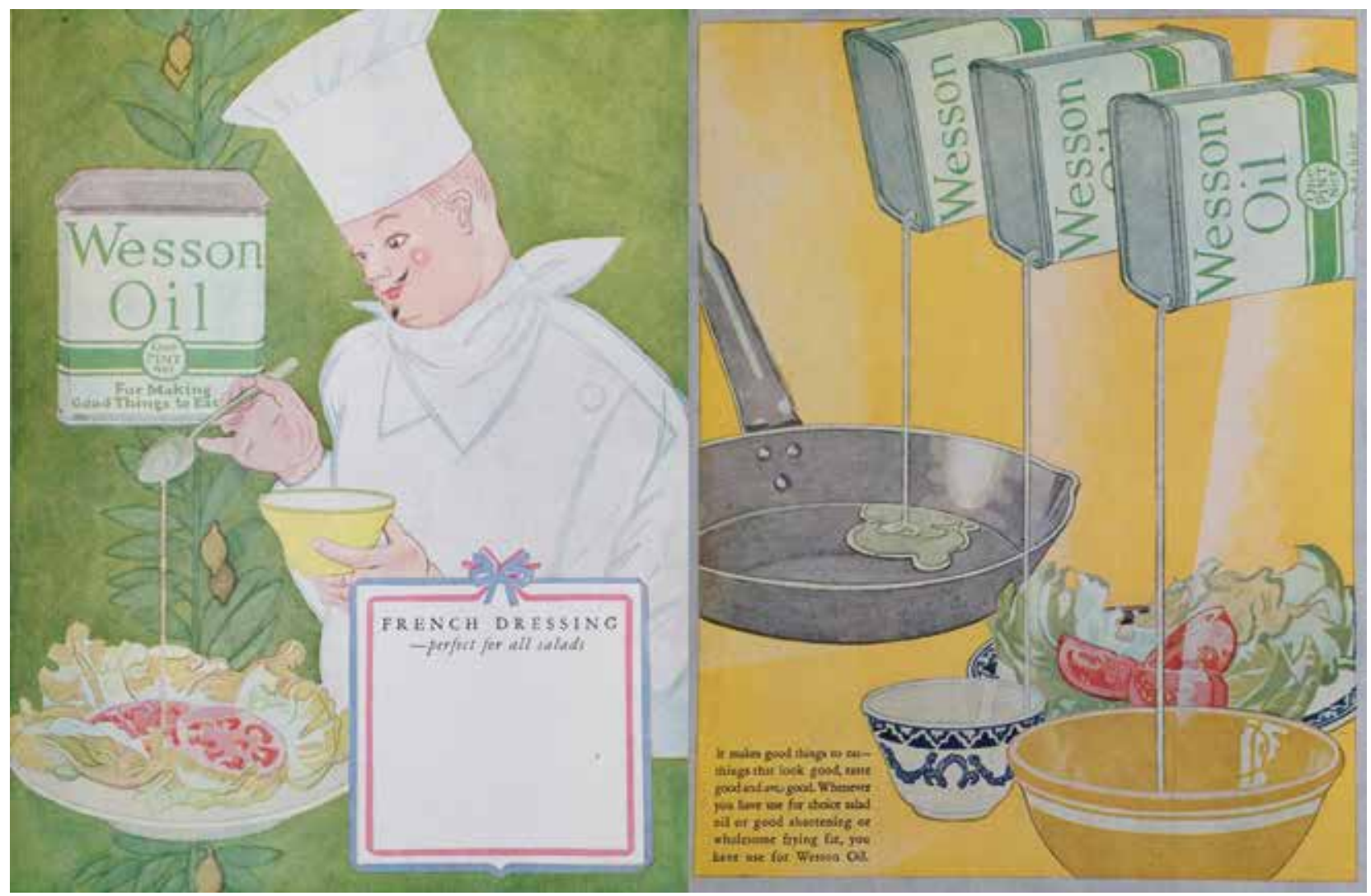

4. Réne Clarke, Reklame za Wesson Oil (preuzeto iz: Gebrauchsgraphik, 10 (1927.), 7, 10) / Réne Clarke, Advertisements for Wesson Oil (source: Gebrauchsgraphik, 10 (1927), 7, 10)

\section{Inozemni uzori i Glumčeva rješenja}

Među autorima koji su svojim reklamnim kampanjama pridonijeli kreiranju obrazaca u oglašavanju ulja kao sastavne namirnice u pripremi hrane ističe se grafički dizajner Réne Clarke, umjetnički direktor poznate američke reklamne agencije Calkins \& Holden, čiji je rad Sergije Glumac vjerojatno dobro poznavao. Clarkeova rješenja za Southern Cotton Oil Company (Wesson Oil \& Snowdrift) bila su tijekom 1920-ih i 1930-ih publicirana na stranicama popularnog i utjecajnoga stručnog časopisa Gebrauchsgraphik kao primjer individualnog stila koji potvrđuje da »vrhunska umjetnička forma proizvodi najveću oglašivačku vrijednost ${ }^{26}{ }^{26}$ Calkins \& Holden umjetničkom su se kvalitetom oglasa isticali među ostalim newyorškim agencijama, a u kampanji za Wesson Oil verbalnu komponentu zamijenili su Clarkeovim persuazivnim crtežima koji su američke domaćice trebali uvjeriti da umjesto životinjskih masti počnu koristiti tekuće, biljno ulje. ${ }^{27}$ Clarke je 1920-ih uspostavio i primjenjivao standarde karakteristične za oglašavanje prehrambenih artikala koje će u svojim rješenjima za Prvu hrvatsku tvornicu ulja koristiti i redefinirati Sergije Glumac koji je zahvaljujući boravcima u inozemstvu i praćenju stručnih publikacija dobro poznavao aktualne tendencije u oglašavanju. U Clarkeovim brojnim rješenjima koja su objavljena u Gebrauchsgraphik dominira motiv izlijevanja ulja u različitim fazama pripreme jela pri čemu se vizualnim sredstvima jasno potencira privlačnost hrane začinjene Wesson uljem. Pri tome Clarke kombinira leksik različite provenijencije - od realističkih i detaljnih crteža hrane, prikaza simpatičnog kuhara koji je tipologijom i oblikovanjem blizak likovima iz onodobne popularne štampe i stripova, do daljnjih odjeka avangardnih tendencija u primjeni netipičnih rakursa ili apstraktno riješenih artdécoovskih pozadina koje se povremeno pojavljuju na njegovim oglasima (sl. 4).

Tijekom međuratnog razdoblja Glumac je za popularne proizvode Prve hrvatske tvornice ulja oblikovao niz skica za oglase i plakate te makete i nacrte publikacija u različitim stupnjevima vizualizacije i verbalizacije ideje. Njegovo oblikovanje variralo je od stiliziranih skica s naznakama avangardnih tendencija u reklamiranju proizvoda široke potrošnje (npr. Prima stolno ulje, ${ }^{28}$ sl. 5) do konvencionalnih rješenja u kojima je naglasak bio na vještom realističkom crtežu i snažnom koloritu (knjižice recepata). Karakter narudžbe nerijetko je uvjetovao vizualizaciju te je Glumac u oblikovanju letaka i plakata namijenjenih trenutačnoj percepciji na ulici primjenjivao simplificirana, efektna i uočljiva rješenja, dok je u oblikovanju knjižica s receptima i uputama za kuhanje namijenjenima korištenju u doma- 


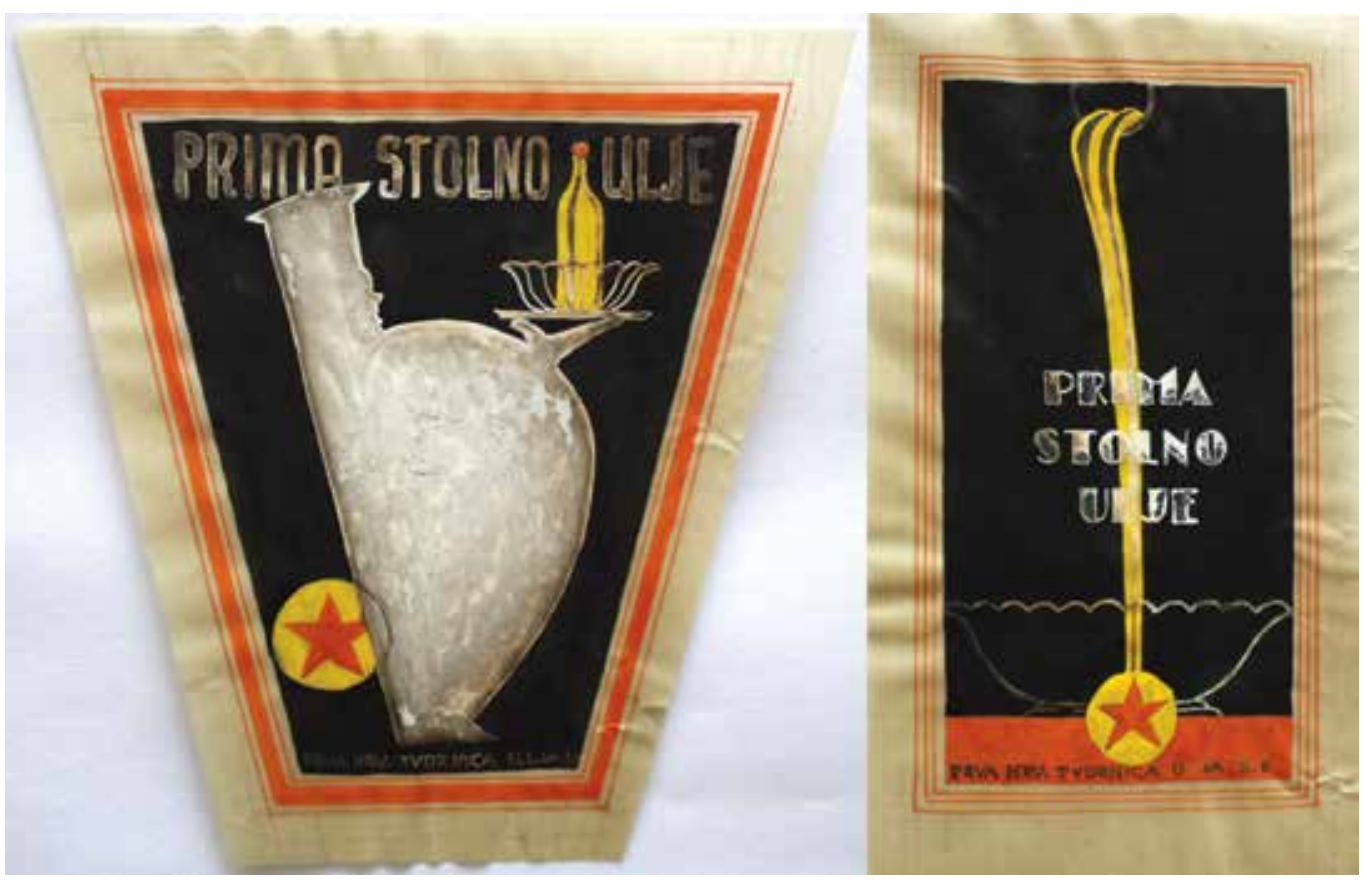

5. Sergije Glumac, Skice za Prima stolno ulje, kraj 1920-ih / početak 1930-ih (Grafička zbirka Nacionalne i sveučilišne knjižnice, Zagreb) / Sergije Glumac, Sketches for Prima cooking oil, late 1920s / early 1930s (Print Collection of the National and University Library, Zagreb)

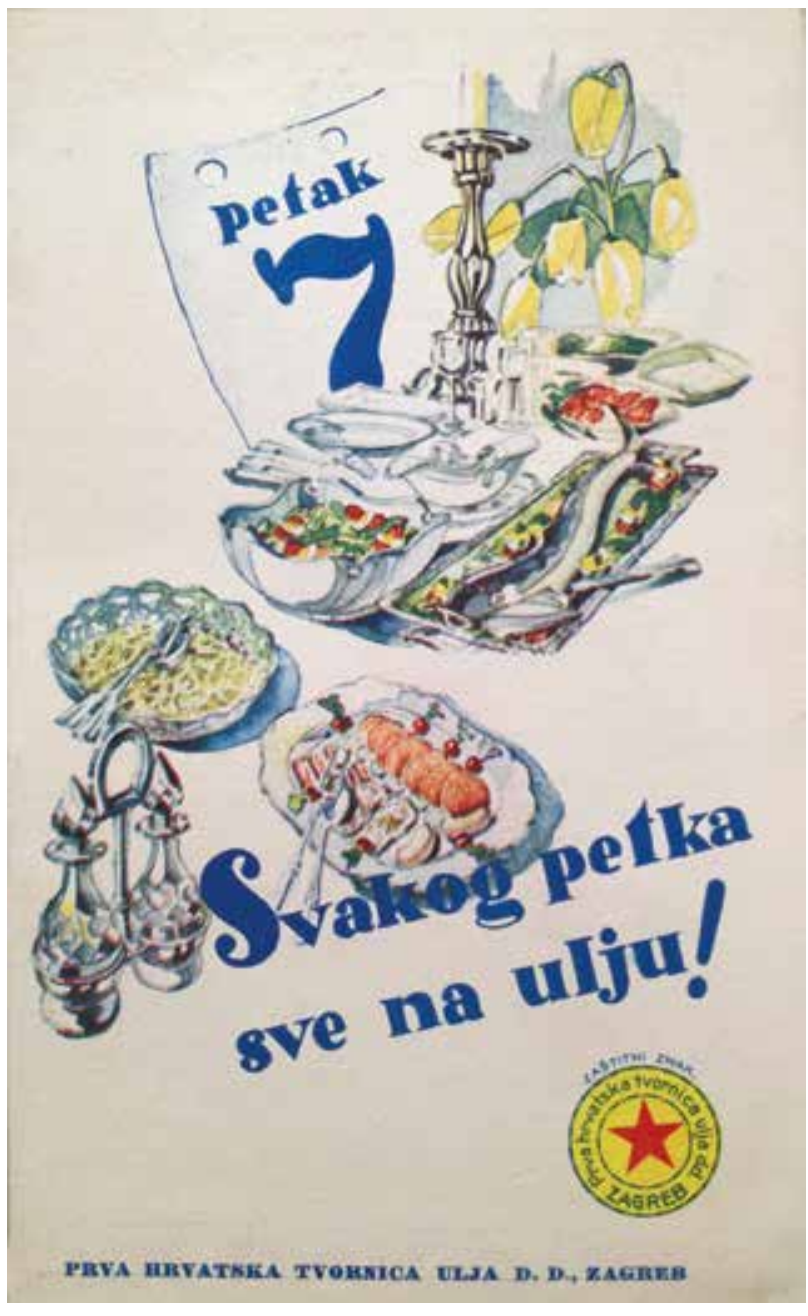

ćinstvu upotrebljavao realistički, dopadljiv crtež s motivima bogate trpeze, voća, povrća i ostalih namirnica (sl. 6).

Brojne sačuvane nerealizirane i realizirane skice za plakate, knjižice recepata ili oglase u različitim tehnikama (olovka, akvarel, tempera itd.) pokazuju da je Glumac temeljito promišljao svaki pojedinačni zadatak i značajnu pozornost posvećivao odnosu slike i teksta te vizualnim sredstvima nastojao konstruirati dodatna značenja i jasno prenijeti poruku. Nerijetko je koristio crteže koji su imali opisni karakter, naglašavali novitete u poslovanju, cijeni ili veličini i obliku pakiranja (boce, kante) ili slikom i sloganima sugerirali način proizvodnje i činjenicu da je ulje Crvena zvijezda »sasvim prirodan i čisti proizvod bilja, zraka i sunca«. Glumac je u kreiranju imagea proizvoda u nizu skica (slikovnih i tekstualnih) primjenjivao različite marketinške tehnike koje je koristio u oblikovanju reklamnih kampanja za druge naručitelje. Redovito je prikazivao potencijalne korisnike (ženu, djecu) i isticao autoritete (liječnika, kuhara) koji su svojim položajem »jamčili« za kvalitetu proizvoda i njegovu zdravstvenu prednost, odnosno naglašavali vrijednost koja se dobiva za povoljnu cijenu ili isticali važnu ulogu proizvoda u održavanju vitalnosti tijela ${ }^{29}($ sl. 7).

6. Sergije Glumac, Svakog petka sve na ulju!, naslovnica knjižice recepata, 1934. (Grafička zbirka Nacionalne i sveučilišne knjižnice, Zagreb) / Sergije Glumac, Every Friday All with Oil!, cooking book cover, 1934 (Print Collection of the National and University Library, Zagreb) 


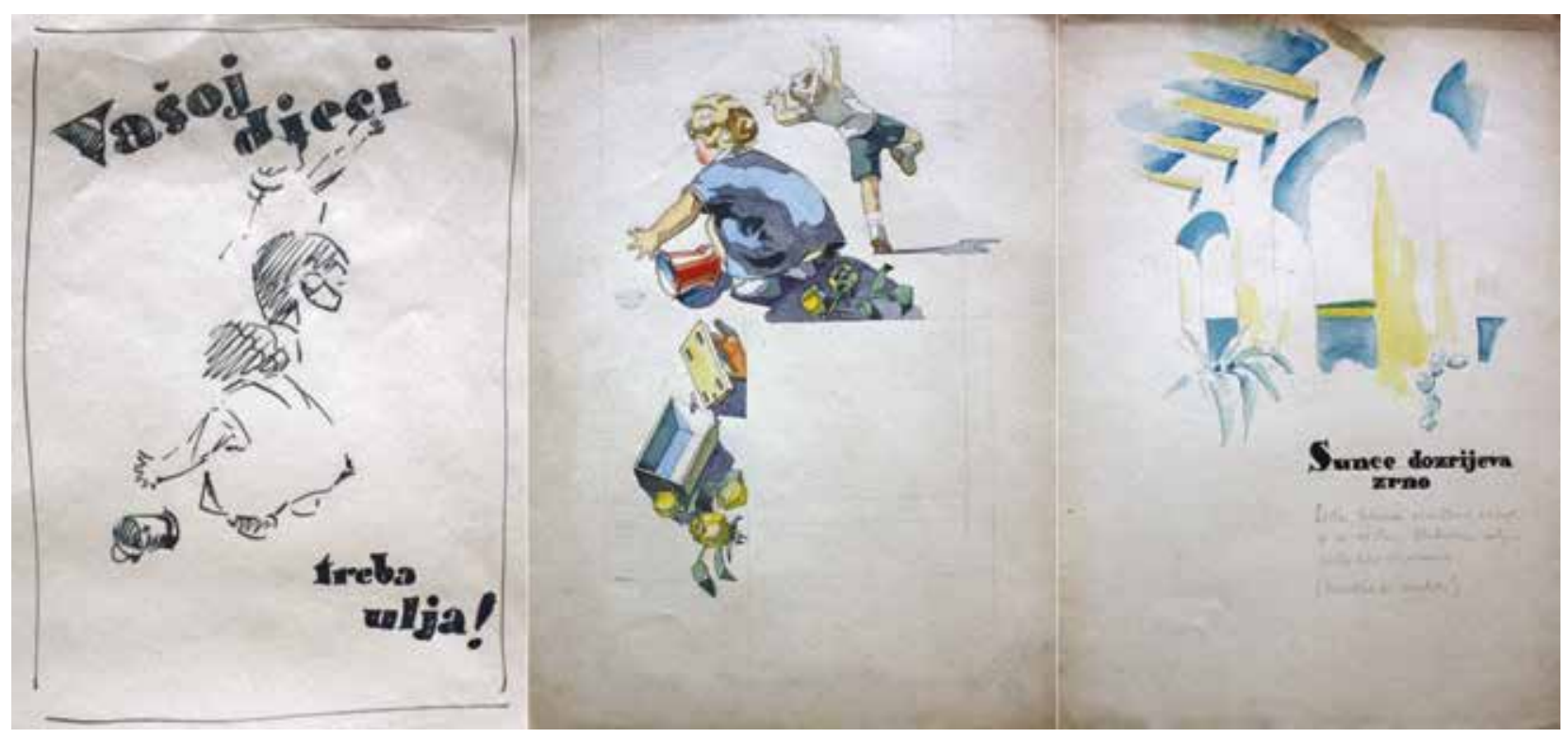

7. Sergije Glumac, Skice različitih verzija oglasa za Prvu hrvatsku tvornicu ulja, oko 1934. (Grafička zbirka Nacionalne i sveučilišne knjižnice, Zagreb) / Sergije Glumac, Advertisement sketches for the First Croatian Oil Factory, c. 1934 (Print Collection of the National and University Library, Zagreb)

\section{»Kuhanje na ulju «- reklamna kampanja iz 1934.}

Početkom 1930-ih svakodnevno korištenje ulja u kućanstvu pri pripremi jela nije bilo uobičajeno: uglavnom se upotrebljavalo u pripremi salata i majoneza, a domaćice su prednost davale kuhanju jela na drugim masnoćama s obzirom na to da je među građanstvom bila prisutna predrasuda da »jelo skuhano na ulju nije tako dobro i tečno ${ }^{30}{ }^{30} \mathrm{Zbog}$ toga je reklamna djelatnost Prve hrvatske tvornice ulja bila usmjerena ponajprije na informiranje javnosti o zdravstvenim i nutritivnim prednostima ulja te intenzivnu kampanju koja je trebala proširiti tržište i osvojiti nove korisnike, odnosno poučiti pučanstvo da se sva jela mogu spremati na ulju. Propagandna aktivnost posebno se razgranala tijekom 1934. kada je pokrenuta višemjesečna intenzivna kampanja pod sloganom »Kuhanje na ulju« koja se provodila u različitim smjerovima. U detaljnom reklamnom planu Prve hrvatske tvornice ulja za jesen 1934. bile su razrađene različite faze realizacije kampanje - od simultanog korištenja više oblika oglašavanja, detaljne razrade termina plakatiranja i datuma i ritma objave različitih oglasa u dnevnim novinama, do dijeljenja propagandnih materijala (knjiga o kuhanju na ulju), organizacije predavanja i predstavljanja na Ugostiteljskom kongresu na Zagrebačkom zboru. ${ }^{31}$

U trenutku kada je ekonomska kriza koja je pogodila hrvatsku privredu od 1930. do 1934. počela postupno popuštati, ${ }^{32}$ intenzivna reklamna kampanja trebala je potaknuti građanstvo da razmotri nove mogućnosti pripreme hrane te počne svakodnevno i redovito koristiti ulje umjesto svinjske masti. Propagandne aktivnosti koje su trebale pridonijeti popularizaciji ulja varirale su od standardnih oblika oglašavanja (plakati, oglasi) do kinoreklame, organizacije specijalnih događaja poput demonstracija »savremenih načina kuhanja na ulju « ${ }^{33}$ ili korištenja novih vrsta reklame (oglasa na kandelabrima $)^{34} \mathrm{i}$ personaliziranog pristupa. Širenje uobičajenih oblika i načina tržišnog komuniciranja trebalo je pridonijeti prisutnosti proizvoda u tkivu grada te njegovoj prepoznatljivosti, odnosno utjecati na interes domaćica i povećanje potrošnje. Sve planirane aktivnosti u konačnici nisu provedene te je izostalo objavljivanje serije Glumčevih oglasa u Jutarnjem listu i Novostima. ${ }^{35}$ Unatoč tomu, opsežna reklamna kampanja koju je koordinirao Glumac realizirala se na globalnoj i individualnoj razini. Tijekom jeseni otisnuta je velika naklada plakata u dvije dimenzije i letaka koje je Prva hrvatska tvornica ulja naručila od Zakladne tiskare Narodnih novina. ${ }^{36}$ Preko tisuću Glumčevih plakata tijekom listopada i studenoga preplavilo je zagrebačke trgove i ulice u centru i periferiji, ${ }^{37}$ a dijapozitivi s istim motivom prikazivali su se u kinima. ${ }^{38}$ Osim intenzivnog plakatiranja, pred Božić je uslijedio i personalizirani pristup. ${ }^{39}$ Građane se stimuliralo da iskušaju proizvod i na kućne adrese im se slalo primjerke besplatnih uzoraka boca »našeg finog, savršeno čisto rafiniranog ulja« i knjige Kuhanje na ulju Štefanije Bernas, autorice nekoliko kuharica i priručnika za domaćice ${ }^{40}(\mathrm{sl} .8 \mathrm{ab})$.

Glumac je na stiliziranoj naslovnici knjige Štefanije Bernas i realiziranom plakatu sa sloganom »bolje je kuhati na ulju i jeftinije« posegnuo za formulom prepoznatljivom širokoj populaciji. ${ }^{41}$ Uobičajeni obrazac za reklamiranje uljanih proizvoda u međuratnom razdoblju (prikaz boce iz koje se izlijeva ulje na neko jelo ili u posuđe) interpre- 


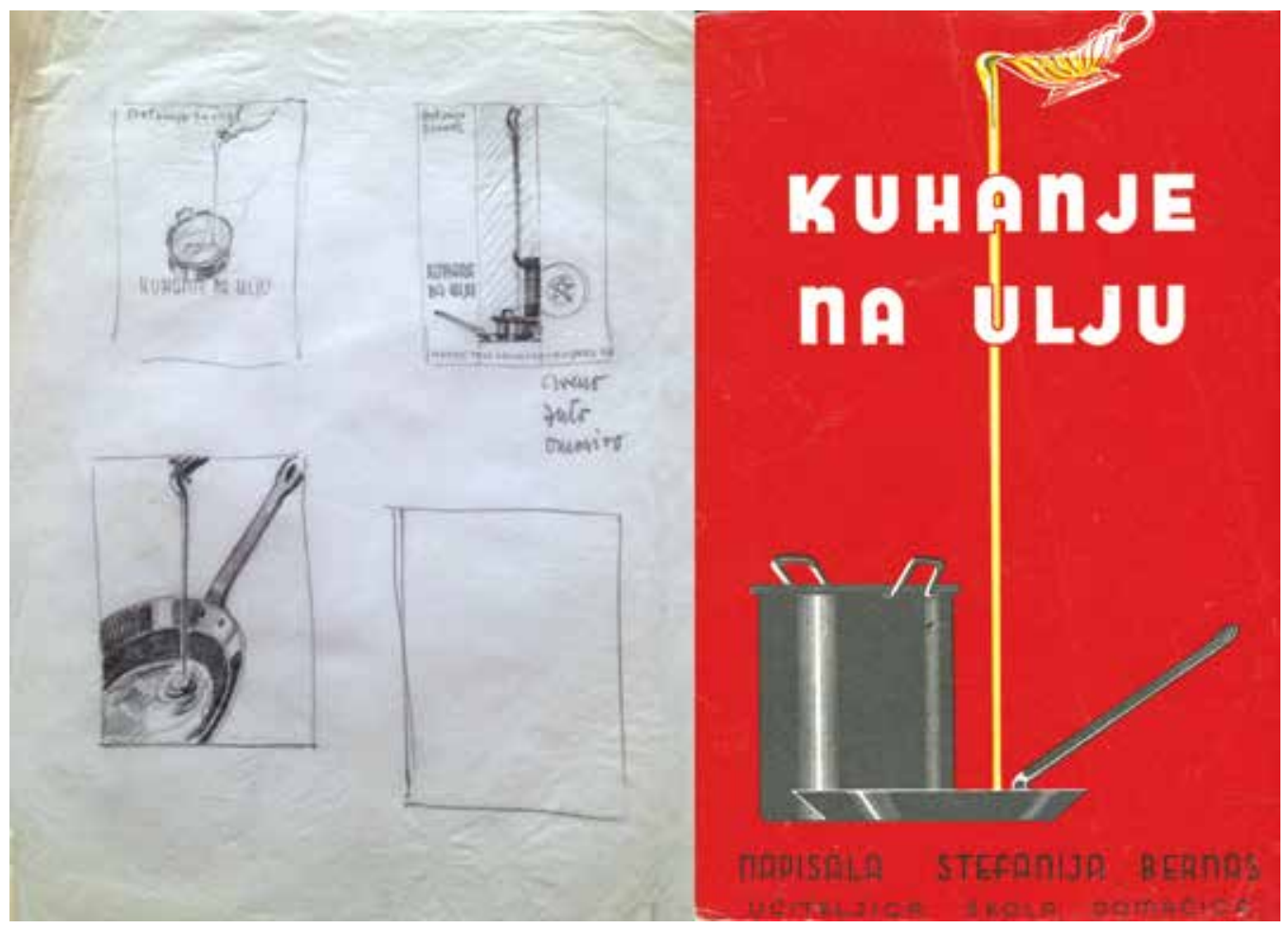

8a. Sergije Glumac, Skice različitih rješenja naslovnice knjige Štefanije Bernas Kuhanje na ulju, 1934. (Grafička zbirka Nacionalne i sveučilišne knjižnice, Zagreb); 8b. Sergije Glumac, Naslovnica knjige Štefanije Bernas Kuhanje na ulju, 1934. (privatno vlasništvo) / 8a. Sergije Glumac, Sketches for the cover of Sttefanija Bernas's book Cooking with Oil, 1934 (Print Collection of the National and University Library, Zagreb); 8b. Sergije Glumac, Cover of Štefanija Bernas's book Cooking with Oil, 1934 (private collection)
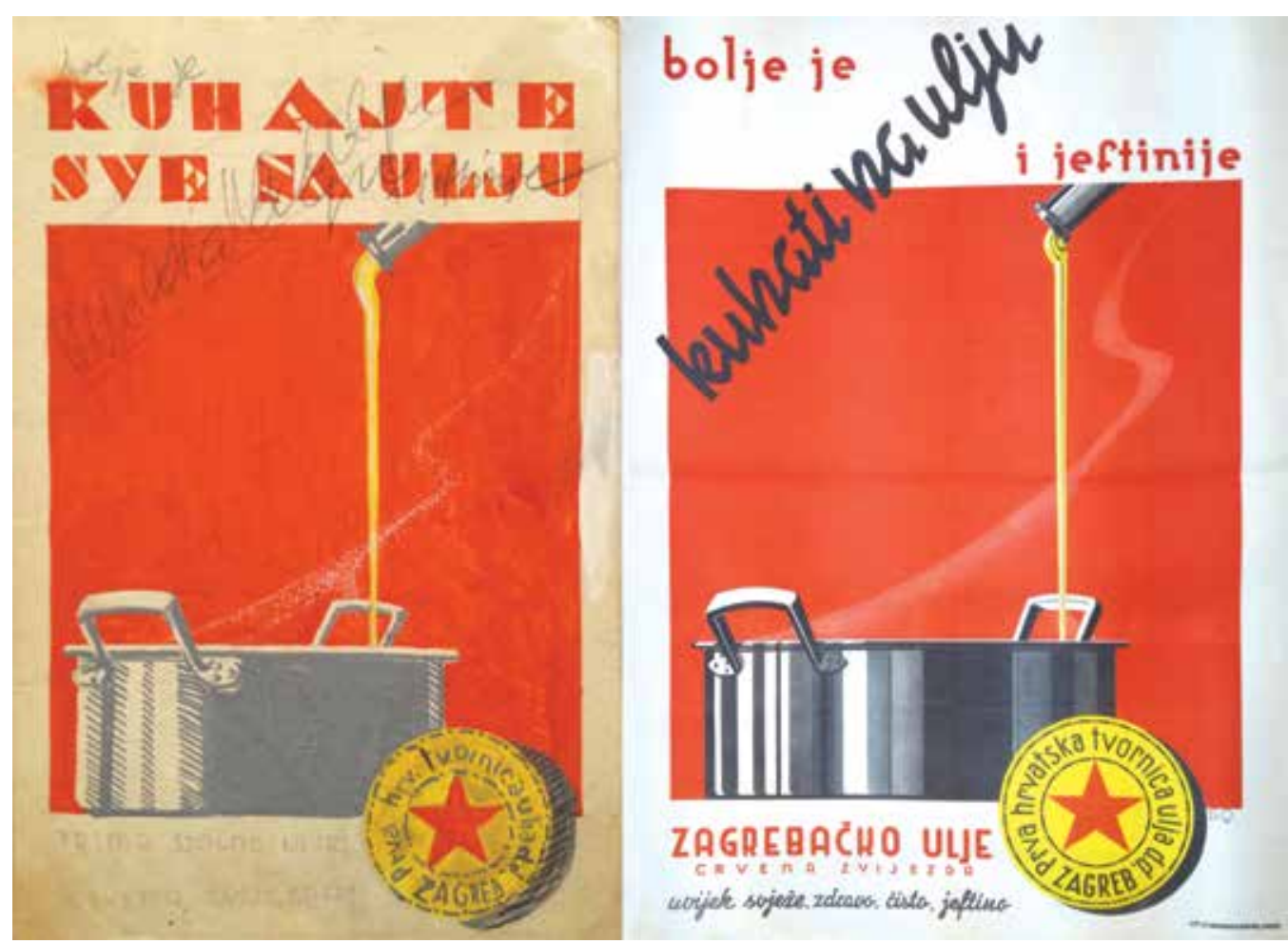

9a. Sergije Glumac, Skica za plakat, 1934. (Grafička zbirka Nacionalne i sveučilišne knjižnice, Zagreb); 9b. Sergije Glumac, Zagrebačko ulje Crvena zvijezda, 1934. (Kabinet grafike HAZU, Zagreb) / 9a. Sergije Glumac, Poster sketch, 1934 (Print Collection of the National and University Library, Zagreb); 9b. Sergije Glumac, Zagreb Red Star Oil, 1934 (Department of Prints and Drawings of the Croatian Academy of Sciences and Arts, Zagreb) 


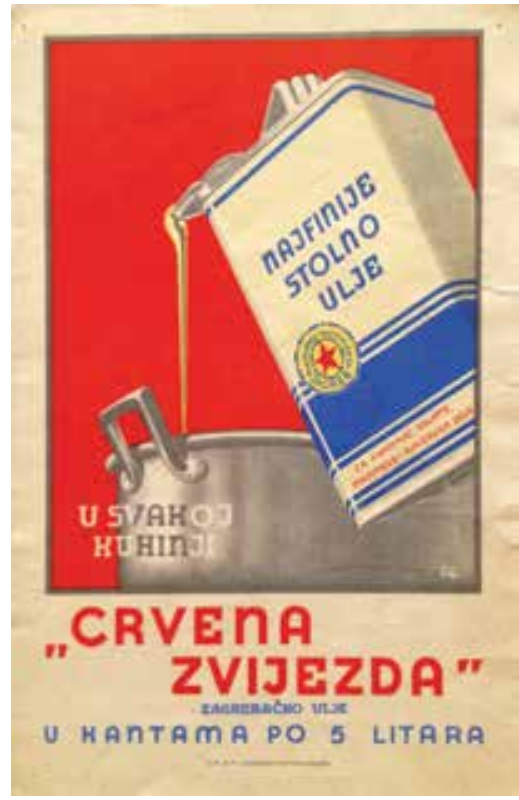

10. Sergije Glumac, Crvena zvijezda u kantama po 5 litara, naslovnica knjižice recepata, 1935.-1937. (Grafička zbirka Nacionalne i sveučilišne knjižnice,

Zagreb) / Sergije Glumac, Red Star in

5-Litre Containers, cooking book cover, 1935-1937 (Print Collection of the National and University Library, Zagreb)

tirao je na nov i moderan način te uspostavio konotativni odnos slike i popratnog teksta koji se razlikovao od reklama glavnog konkurenta Meinla. ${ }^{42}$ Primijenio je netipično kompozicijsko rješenje slike unutar slike: crvena ploha $\mathrm{s}$ prikazom izlijevanja ulja iz vrška boce u lonac smještena je unutar bijelog okvira kojim dominiraju natpisi i zaštitni znak tvornice koji ih spaja, a odabir prepoznatljivih boja (crvene i žute) dodatno je pridonio efektnosti plakata. Dok su na nacrtu plakata slika i tekst (prvotni slogan »kuhajte sve na ulju«) bili odvojeni, u finalnom su rješenju isprepleteni te dodatno naglašeni različitom tipografijom i bojom (sl. 9 ab). Plakatom dominira crvena pozadina koja je tankim mlazom ulja podijeljena gotovo po zakonu zlatnog reza te kojom se izvija opojni miris ukusne hrane pripremljene na Crvenoj zvijezdi. Jednostavno, pročišćeno i efektno rješenje vizualno korespondira »uvijek svježem, zdravom, čistom i jeftinom ulju «, a senzorna kvaliteta plakata (vizualiziranje elegantnog mirisa) garantira ono što je tekstom jasno naglašeno i obećano - bolje i jeftinije kuhanje. Naime, reklamni slogani za Crvenu zvijezdu redovito su naglašavali njezine prednosti u odnosu na konkurenciju - da je riječ o domaćem proizvodu (zagrebačkom ulju) koji je jeftiniji od uvoznih ulja, ali iste kvalitete.

Reklamna kampanja obraćala se prije svega domaćicama i majkama, a popratni letak s motivom Glumčeva plakata oglašavao je novopubliciranu knjigu Štefanije Bernas te naglašavao zdravstvene i ekonomske prednosti ulja. Apeliralo se na osjećaj potrošačica za kućni budžet $\mathrm{i} »$ borbu protiv skupoće«, njihovu brigu za zdravlje ukućana (posebno djece), te ih se uvjeravalo u preventivne i izlječiteljske kvalitete proizvoda koji je »riznica prirodnih bogatstava«i nagovaralo da iskušaju kuhanje na ulju. ${ }^{43}$

Sačuvane fotografije izložbenih mjesta Prve hrvatske tvornice ulja na Zagrebačkom zboru pokazuju da je plakat iz 1934. korišten i narednih godina, ${ }^{44}$ a 1937. Glumac je oblikovao novo, srodno rješenje s dominantnom crvenom pozadinom i motivom izlijevanja ulja iz kante popraćeno sloganom »najfinije stolno ulje / u svakoj kuhinji« (sl. 10). Novo rješenje također je korišteno na različitim materijalima (plakatima, letcima i naslovnicama niza knjižica recepata), a njime se ponajprije oglašavalo pakiranje ulja od pet litara i široko korištenje proizvoda u domaćinstvu. ${ }^{45}$ Plakatu su prethodile skice s drugačijom organizacijom elemenata kompozicije (kante ulja i lonca), a ostali su sačuvani i prijedlozi s prikazom ulja kao »sunčane zrake na Vašem stolu« (sl. 11).

\section{Oblikovanje izložbenih prostora i ostali oblici Glumčeve suradnje s Prvom hrvatskom tvornicom ulja}

Glumac je tijekom 1930-ih za različite naručitelje oblikovao izlagalačke prostore na gospodarskim manifestacijama, ${ }^{46} \mathrm{a}$ za Prvu hrvatsku tvornicu ulja koordinirao je predstavlja- 


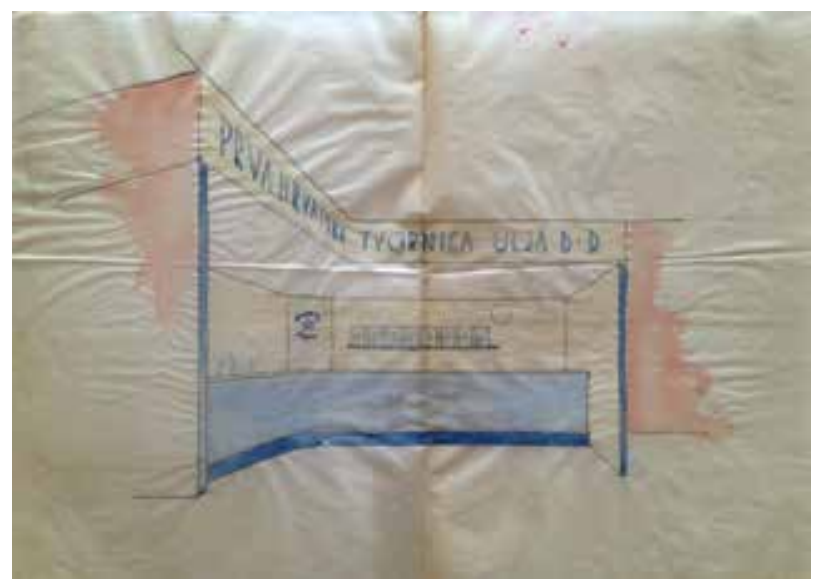

12. Sergije Glumac, Prijedlog rješenja izložbenog paviljona Prve hrvatske tvornice ulja, oko 1935.-1937. (Grafička zbirka Nacionalne i sveučilišne knjižnice, Zagreb) / Sergije Glumac, Proposal for the layout of the First Croatian Oil Factory exhibition pavilion, c. 1935-1937 (Print Collection of the National and University Library, Zagreb)

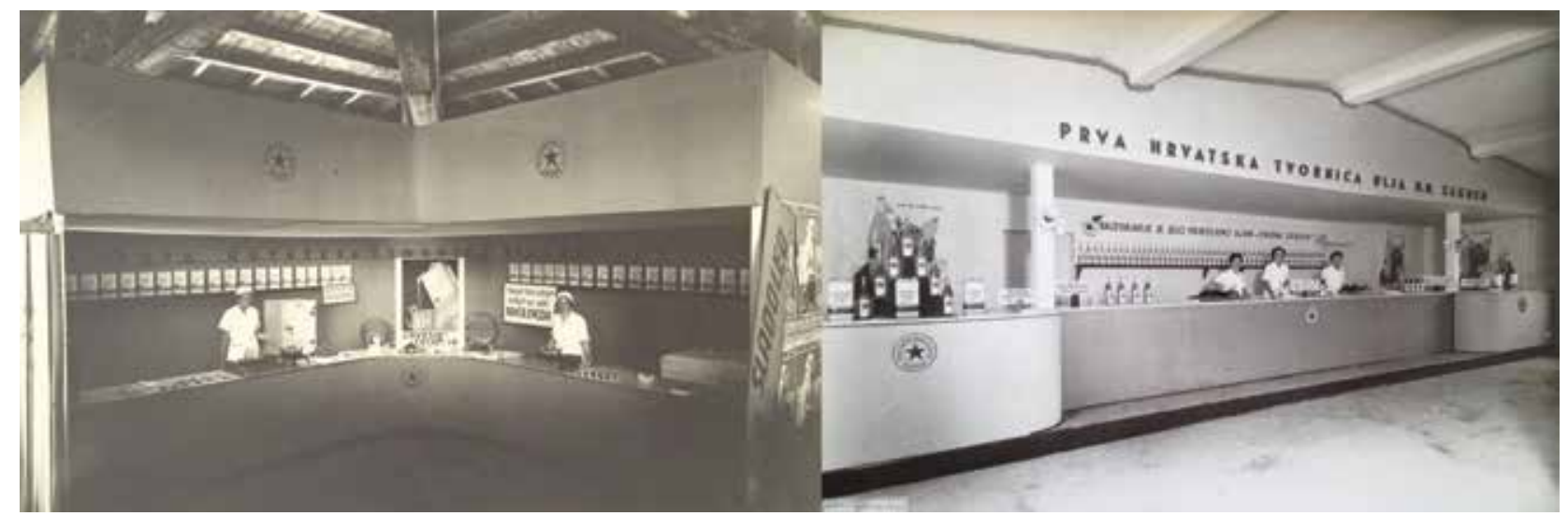

13a. Prva hrvatska tvornica ulja na 17. ljubljanskom velesajmu, 1937. (Grafička zbirka Nacionalne i sveučilišne knjižnice, Zagreb); 13b. Foto Donegani, Prva hrvatska tvornica ulja na Specijalnom sajmu prehrambene industrije na 32. zagrebačkom zboru, 1939. (Državni arhiv u Zagrebu, Fond 251. Zagrebački zbor (1909.-1945), kut. 182) / 13a. First Croatian Oil Factory at the $17^{\text {th }}$ Ljubljana Fair, 1937 (Print Collection of the National and University Library, Zagreb); 13b. Foto Donegani, First Croatian Oil Factory at the Special Food Industry Fair, $32^{\text {nd }}$ Zagreb Fair, 1939 (Zagreb State Archives, Fonds 251. Zagreb Fair (1909-1945), box 182)

nje na Zagrebačkom zboru i Ljubljanskom velesajmu. Prva hrvatska tvornica ulja redovito se predstavljala na Zagrebačkom zboru i sudjelovala u popratnim manifestacijama poput reklamnog korza koji je upriličen u povodu Izložbe reklame 1934. ${ }^{47}$ Glumčeve skice izložbenih prostora predstavljale su materijalizaciju temeljnih teorijskih postavki suvremene reklamne znanosti koja je propisivala da izložbeni štandovi, paviljoni i izlozi dućana trebaju biti »moderni, ukusni i uredni«, a naglasak stavljen na samu robu, dok sva ostala dekoracija treba biti u funkciji njezina isticanja i pojačavanja dojma potrošača. ${ }^{48}$ Sukladno tomu, Glumčeva različita rješenja za prezentaciju tvornice na gospodarskim sajmovima iz druge polovine 1930-ih (tlocrte, nacrte i perspektive štandova) obilježava minimalistički dizajn i svijest o kontraproduktivnosti neurednih i natrpanih izložbenih mjesta ${ }^{49}$ (sl. 12). Čistim linijama i urednom organizacijom prostora nastojala se privući pozornost posjetitelja, a prezentacijom artikala trebalo se nenametljivo utjeloviti karakter ulja reklamiranog riječima "uvijek svježe, zdravo, čisto i jeftino«. Sačuvane fotografije izložbenih prostora Prve hrvatske tvornice ulja na Zagrebačkom zboru (1936., 1937. i 1939.) i Ljubljanskom velesajmu (1937.) pokazuju jednostavnu, pročišćenu i simetričnu organizaciju. Eliminacijom suvišnih detalja do izražaja su došli naziv i zaštitni znak tvornice, uredno složeni proizvodi koji su formirali kontinuirani friz te Glumčevi efektni plakati koji su bili smješteni u središtu ili flankirali izložbena mjesta (sl. 13 ab). Sačuvane fotografije imaju i značajnu dokumentarnu vrijednost: pokazuju danas nesačuvano rješenje plakata koje je 1939. odabrano za kampanju kojom se pod geslom »ovakovo ulje još niste mogli dobiti« reklamirala Crvena zvijezda u originalno punjenim bocama. Među nekoliko različitih skica koje su naglašavale podrijetlo ulja od suncokreta ili popratnu parolu »iz tvornice $\mathrm{u}$ kuhinju u u konačnici je realizirano jednostavno, pomalo tradicionalno rješenje $s$ bocom ulja i košaricom punom namirnica koje je blisko Glumčevu ranijem oblikovanju knjižica recepata (sl. 14).

U navedenom razdoblju Glumčeva intenzivna suradnja s tvornicom manifestirala se i na drugim razinama. Umjetnik je za Uljaru u grafičkim tehnikama izrađivao prigodne novogodišnje čestitke na kojima su dominirali prepoznatljivi motivi Zagreba (npr. tržnice i katedrale, 1937.) ili tvornice (1938.), ${ }^{50}$ a 1930-ih također je realizirao seriju crteža ugljenom i pojedinačne grafičke listove s motivima tvorničkih postrojenja i dvorišta u Branimirovoj ulici u kojima je do izražaja došla njegova kontinuirana fascinacija tehnologijom i monumentalnim tvorničkim konstrukcijama (sl. 15).

Tijekom 1930-ih Glumac je za Prvu hrvatsku tvornicu ulja oblikovao prepoznatljiv i moderan vizualni identitet koristeći uobičajene i široko rasprostranjene formule prisutne 


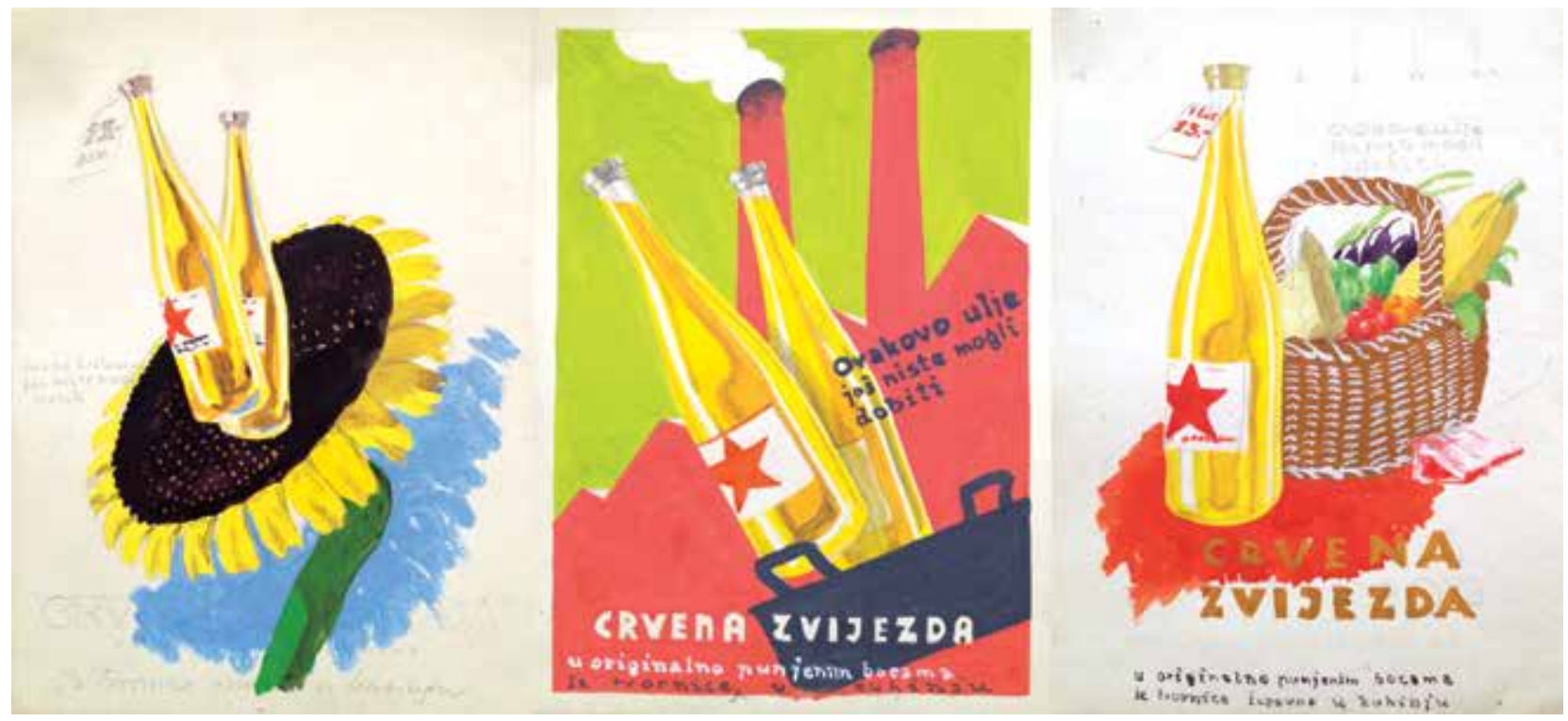

14. Skice plakata Crvena zvijezda u originalno punjenim bocama, 1939. (Grafička zbirka Nacionalne i sveučilišne knjižnice, Zagreb) / Originally Bottled Red Star poster sketches, 1939 (Print Collection of the National and University Library, Zagreb)

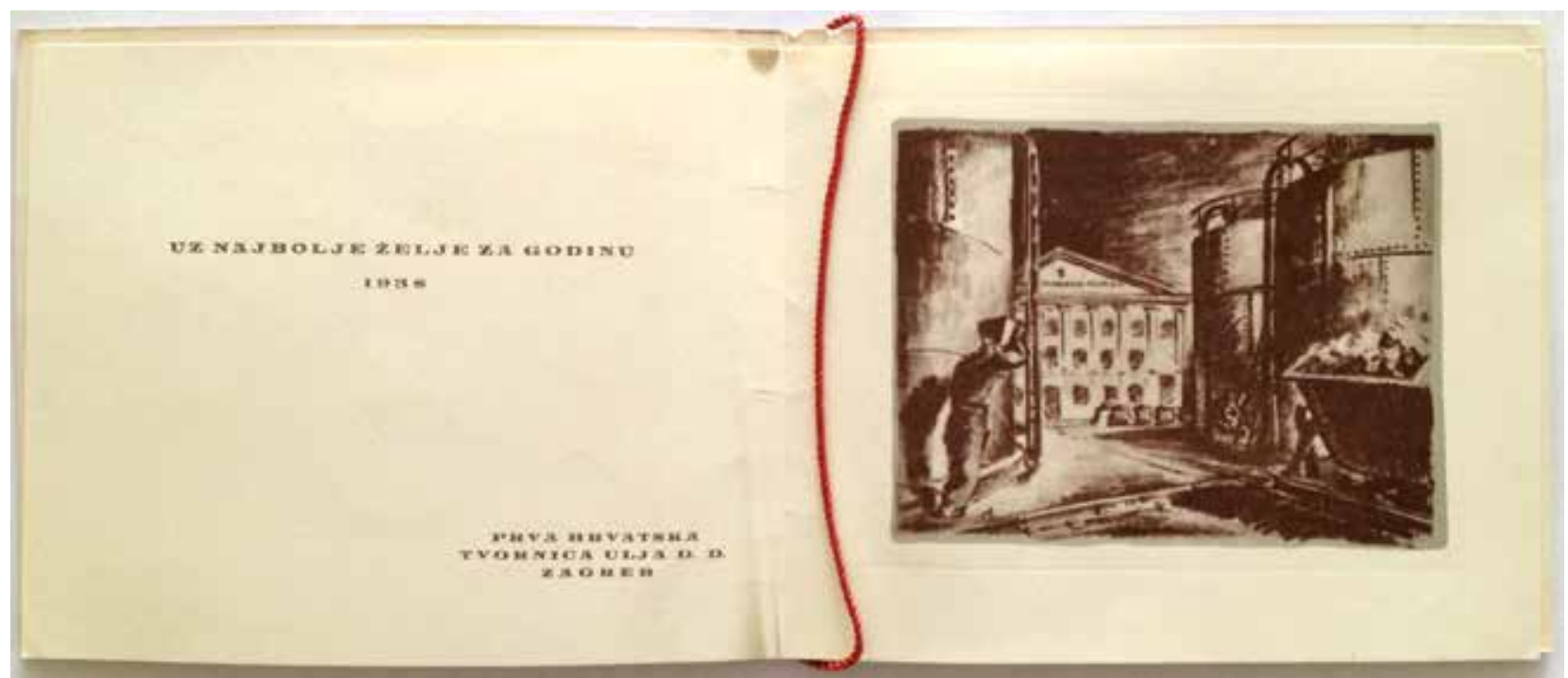

15. Sergije Glumac, Novogodišnja čestitka Prve hrvatske tvornice ulja za 1938., 1937. (Grafička zbirka Nacionalne i sveučilišne knjižnice, Zagreb) / Sergije Glumac, 1938 New Year greeting card of the First Croatian Oil Factory, 1937 (Print Collection of the National and University Library, Zagreb)

u oglašavanju ulja te transponirajući ih na nov i suvremen način. U njegovim efektnim rješenjima (posebno onima za kampanju 1934.) prisutni su stilizacija prikazanih motiva, apeliranje na identifikaciju potencijalnih potrošačica te upotreba jasnih i pamtljivih slogana koji su pridonijeli uspješnom prenošenju poruke. Njegova moderna rješenja za Prvu hrvatsku tvornicu ulja, ali i za Zagrebačku dioničku pivovaru i tvornicu slada, ističu se u kontekstu onodobnoga grafičkog dizajna namijenjenog oglašavanju prehrambene industrije te uz radove Pavla Gavranića predstavljaju značajan odmak od uvezenih, ilustrativnih i/ili tradicionalnih obrazaca koji su bili uobičajeni u reklamiranju namirnica svakodnevne potrošnje.

Modernim plakatima i osmišljenom prezentacijom proizvoda Prve hrvatske tvornice ulja Sergije Glumac značajno je pridonio visokim standardima oglašavanja prehrambene industrije u Kraljevini Jugoslaviji tijekom međuratnog razdoblja te udario temelje kvalitetnog i uspješnoga vizualnog identiteta tvornice koji će se nastaviti i nakon Drugoga svjetskog rata. Iako se 1946. mijenjaju vlasnička struktura i naziv, ${ }^{51}$ svijest o važnosti propagandnog djelovanja i ulozi grafičkog dizajna u osvajanju tržišta nastavit će se u posli- 
jeratnom razdoblju uspješnim rješenjima Zvonimira Faista i drugih autora ${ }^{52}$ čiji su persuazivni oglasi i plakati slijedili raniju tradiciju te pridonijeli plasiranju novih proizvoda i istaknutom položaju zagrebačke Tvornice ulja u prehrambenoj industriji onodobne Jugoslavije.*

\section{BILJEŠKE}

* Ovaj rad je sufinancirala Hrvatska zaklada za znanost projektom br. 4153, Croatia and Central Europe: Art and Politics in the Late Modern Period (1780-1945).

1 U literaturi posvećenoj povijesti hrvatskoga grafičkog dizajna Glumčeva se suradnja s Prvom hrvatskom tvornicom ulja (dalje: PHTU) ne spominje. Predrag Haramija uključio je plakat Zagrebačko ulje (Kabinet grafike HAZU, inv. br. KG HAZU 1590) u izložbu Majstori hrvatskog plakata: Pavao Gavranić / Sergije Glumac, ali s netočnom datacijom (1950. umjesto 1934.). Usp. PREDRAG HARAMIJA, Majstori hrvatskog plakata: Pavao Gavranić / Sergije Glumac, katalog izložbe, Kabinet grafike HAZU, Zagreb, 1994., 23. O Glumčevu grafičkom dizajnu i suradnji s PHTU-om detaljno je pisano u: LOVORKA MAGAŠ BILANDŽIĆ, Sergije Glumac - život i djelo, doktorska disertacija, Filozofski fakultet Sveučilišta u Zagrebu, Zagreb, 2012., 252-256.

2 Grafička zbirka Nacionalne i sveučilišne knjižnice, Zagreb, Ostavština Sergija Glumca (dalje: GZ NSK, OSG). U ostavštini se čuva niz dokumenata (plan reklame, predračuni, narudžbe, dopisnice i komentari kupaca, izrada reklamnih slogana itd.) koji pokazuju da je umjetnikov angažman nadilazio ulogu grafičkog dizajnera i uključivao razradu reklamne djelatnosti te komunikaciju sa svim dionicima uključenima u oglašavanje $\mathrm{PH}-$ TU-a (tiskarama, reklamnim zavodima, inozemnim stručnjacima itd.).

3 Stogodišnjica osnivanja tvornice obilježena je nizom događanja među kojima se ističe izložba koju je Zvijezda d. d. organizirala u Muzeju suvremene umjetnosti u Zagrebu (20.-27. rujna 2016.) i na kojoj su predstavljeni proizvodi, ambalaža, oglasi itd., uglavnom nastali nakon Drugoga svjetskog rata. Više: Zvijezda.hr, URL: http://www.zvijezda.hr/ retrospektivna-izlozba-msu-zagreb-vremeplov-zvijezdine-proizvode (3. 10. 2016.). Glumčeva rješenja za PHTU nisu bila izložena.

4 Tvornica ulja Zagreb 1916-1966, Zagreb, 1966., 6. O povijesti i razvoju tvornice i u: SALIH ZVIZDIĆ, Tvornica ulja - Zagreb: 1916-1986, Spektar, Tvornica ulja - Zagreb, Zagreb, 1986.

5 Prema podacima iz 1940., posjedovali su 93\% dionica. Iste su godine zbog novonastale političke situacije prisiljeni ustupiti većinu dionica i upravu nad tvornicom Povlaštenom hrvatskom industrijskom trgovačkom d. d. (POHIT-om), a u vrijeme NDH u potpunosti su razvlašteni. Navedeni podaci preuzeti su iz: Tvornica ulja Zagreb 1916-1966 (bilj. 4). 6 M. Dt. [MIROSLAVA DESPOT], "Aleksander, Samuel D. (Alexander)«, Hrvatski biografski leksikon, sv. 1, (ur.) Nikica Kolumbić, Jugoslavenski leksikografski zavod, Zagreb, 1983., 71-72; IVAN MIRNIK, Obitelj Alexander ili kratka kronika izbrisanog vremena, Radovi Zavoda za hrvatsku povijest, 28 (1995.), 101-103.

7 M. Dt. [MIROSLAVA DESPOT], »Aleksander, Šandor A. (Alexander)«, Hrvatski biografski leksikon, sv. 1, (ur.) Nikica Kolumbić, Jugoslavenski leksikografski zavod, Zagreb, 1983., 72; IVAN MIRNIK (bilj. 6), 105-107.

8 Svi navedeni citati i podaci o tvornici i njezinu djelovanju preuzeti su iz: Tvornica ulja Zagreb 1916-1966 (bilj. 4), 6-7, 23.

9 Više u: LOVORKA MAGAŠ BILANDŽIĆ (bilj. 1).

10 Više o zavodu Imago i Glumčevu tadašnjem djelovanju u: LOVORKA MAGAŠ, Reklamni zavod Imago i komercijalni grafički dizajn u Hrvatskoj 1920-ih, Peristil, 51 (2008.), 99-118.

11 Više u: LOVORKA MAGAŠ BILANDŽIĆ (bilj. 1), 251-252.

12 Državni arhiv u Zagrebu, Fond 109. I. muška realna gimnazija, 1854.-1945. (dalje: HR-DAZG-109), sign. 8 (24162), Urudžbeni zapis- nik 1919.-1922., god. 1920., br. 833. Podatak o braći Aleksander: HRDAZG-109, sign. 64 (23023), Glavni katalog 1920/21.

13 Najstariji brat Ivo Aleksander bio je ravnatelj Zagrebačke dioničke pivovare i tvornice slada, a pravnik Božidar Aleksander vodio je pravne poslove očevih tvornica. Podaci o obrazovanju članova obitelji Aleksander preuzeti su iz: IVAN MIRNIK (bilj. 6) i BORIS ZAKOŠEK, Obitelj Aleksander, Vjesnik Državnog arhiva u Rijeci, 43-44 (2002.), 121-152. 14 Detaljnije o tome u: LOVORKA MAGAŠ BILANDŽIĆ (bilj. 1).

15 Npr. prijedlog reklamiranja tijekom Zagrebačkog zbora izradio je Julius Katz. GZ NSK, OSG, Julius Katz, Vorschlag für eine Werbeaktion der PHTU, Zagreb, 31. 7. 1935.

16 Godine 1931. angažirao je Emila Lenza za dekoraciju i Slavka Batušića za prijevod recepata s njemačkog jezika. Riječ je o najranijim sačuvanim dokumentima koji svjedoče o Glumčevu radu za PHTU. GZ NSK, OSG, Potvrda Slavka Batušića, Zagreb, 18. 8. 1931.; GZ NSK, OSG, Račun Emila Lenza za dekoraciju tvornice ulja, bez datuma.

17 FEĐA VUKIĆ, Stoljeće hrvatskog dizajna, Meandar, Zagreb, 1996., 59.

18 Lakatoš 1929. navodi sljedeću podjelu prehrambene industrije: mlinska industrija, tvornice tjestenine, industrija škroba, industrija šećera, industrija alkohola, pivovare i tvornice leda, tvornice octa, industrija ulja, mesna industrija, industrija konzervi i mlijeka, duhanska industrija. JOSO LAKATOŠ, Privredni almanah Jugoslavenskog Lloyda, Jugoslovenska štampa, Zagreb, 1929., glava V, 24.

19 O oglašavanju prehrambene industrije nije se detaljnije pisalo u povijesti hrvatskoga grafičkog dizajna, a primjeri Crnčićevih i Krizmanovih plakata objavljeni su uz popratne opise u: RENATA GOTTHARDI ŠKILJAN, Plakat u Hrvatskoj do 1941., katalog izložbe, Kabinet grafike JAZU, Zagreb, 3. 2.-8. 3. 1972.; LADA KAVURIĆ, Hrvatski plakat do 1940., Institut za povijest umjetnosti, NSK, Horetzky, Zagreb, 1999., 37, 137; VESNA KEDMENEC KRIŽIĆ, Prvaci hrvatskog plakata: Csikos, Crnčić, Krizman, Babić, katalog izložbe, Kabinet grafike HAZU, Zagreb, travanj-svibanj 2011., 30-31.

20 Gavranić je redefinirao i osuvremenio formulu koju je oko 1910. uspostavio Krizman (Pokornyjev liker Stari graničar oglašavao je likom starog graničara) te dosjetljivim reinterpretiranjem slova "P« stvorio simpatičan lik diznijevske fizionomije koji utjelovljuje optimističku stranu života. Oko 1930. Gavranić je izveo reklame i za druga popularna pića kao što su Vero limonada i Jogura (za Joguru je plakat oblikovao i Krizman). Više o Gavraniću u: VESNA KEDMENEC KRIŽIĆ, Pavao Gavranić: radovi iz Kabineta grafike HAZU, katalog izložbe, Kabinet grafike HAZU, Zagreb, studeni-prosinac 2005.

21 LOVORKA MAGAŠ BILANDŽIĆ (bilj. 1), 249-252. Prikazivanje potencijalnih konzumenata primijenio je već 1910. Crnčić u dvije varijante plakata za Zagrebačku dioničku pivovaru koje su vizualnim sredstvima sugerirale da je popularno pivo namijenjeno svim društvenim slojevima.

22 JOSO LAKATOŠ (bilj. 18), 39.

$23 \mathrm{Na}$ letku za ulje Dubravka koristila se fotografija vizure Dubrovnika, a na brošurama za ulje Riviera (proizvod istoimene Fabrike sapuna, svijeća, sode i rafinerije ulja braće M. i A. Vučkovića iz Kotora) nalazio se detaljni crtež ulja pakiranog u bocama i kantama. Primjerci se nalaze u GZ NSK, OSG.

24 Primjeri reklamnih materijala za Julio Meinl d. d. nalaze se u GZ NSK, OSG.

25 Prepoznatljivi žuti kružni zaštitni znak sastojao se od naziva tvornice i crvene zvijezde u središtu. Ulje Crvena zvijezda tijekom međuratnog razdoblja bilo je glavni proizvod tvornice te se i doslovno nalazilo u njezinu središtu.

26 H. K. FRENZEL, Réne Clarke, Gebrauchsgraphik, 10 (1927.), 2-10.

27 STEPHEN FOX, The Mirror Makers: A History of American Advertising and Its Creators, University of Illinois Press, Urbana, Chicago, 1997., 44 . 
28 Skica s prikazom apstrahirane siluete korpulentnog kuhara koji pažljivo nosi bocu ulja slična je realiziranom plakatu PHTU-a koji prikazuje kuhara iz profila kako nosi kantu ulja Crvena zvijezda. Nepotpisani plakat bio je izložen u MSU-u (vidi bilj. 3), a na osnovi fotografije Fotoateliera Jadran koja prikazuje izložbeno mjesto PHTU-a na 14. zagrebačkom zboru može se datirati u 1930. godinu. Usp. HR-DAZG, Fond 251. Zagrebački zbor 1909.-1945., kut. 172.

29 Brojne skice (olovkom, perom itd.) nalaze se u GZ NSK, OSG.

30 GZ NSK, OSG, Dopis PHTU, Zagreb, 25. 12. 1934.

31 GZ NSK, OSG, Reklamni plan, 1934., rukopis.

32 Više o situaciji u gospodarstvu i industriji vidjeti u: ZDENKA ŠIMONČIĆ-BOBETKO, Industrija Hrvatske od 1918. do 1941. godine, AGM, Zagreb, 2005.

33 Zagrebačka gradska plinara s ciljem je popularizacije potrošnje plina u lipnju 1934. organizirala nekoliko predavanja Angele Howorka iz Beča koja je u Glazbenom zavodu na ulju pripremila kompletan ručak uz degustaciju i prisutnim domaćicama dokazala "prednosti savremene higijene« te kako je »kuhanje na ulju odista savremeni način zgotovljanja jela«. -, Akcija plinare za racionalno trošenje plina u Zagrebu, Jutarnji list, XXIII/8048 (27. lipnja 1934.), 6. Istu predavačicu planirao je angažirati i PHTU (vidi bilj. 31).

34 Unioreklam je sredinom 1930-ih u centru Zagreba započeo s najnovijom vrstom reklame na plinskim kandelabrima. GZ NSK, OSG, Ponuda i skica Unioreklama PHTU, Zagreb, 27. 5. 1935.

35 Planirano je da u razdoblju od 23. listopada do kraja studenoga izađe deset različitih oglasa, ali do njihova objavljivanja nije došlo. Podatak na osnovi uvida u dnevne tiskovine.

36 Naručeno je 1000 plakata $(85 \times 120 \mathrm{~cm})$ za 2720 dinara, 2000 malih plakata na kartonu $(33 \times 50 \mathrm{~cm})$ za 4080 dinara te 45000 letaka $(14,5 \times$ $21,5 \mathrm{~cm})$ za 4930 dinara. GZ NSK, SG, Dopis Zaklade tiskare Narodnih novina u Zagrebu PHTU, Zagreb, 16. 10. 1934.

37 Pri tome su angažirali različite reklamne zavode i zakupili njihova oglasna mjesta: GZ NSK, OSG, Popis mjesta afiširanih plakata tt. Tvornica ulja, Zagreb od Centroreklam, 1. 11. 1934. (500 plakata); GZ NSK, OSG, Popis mjesta izlijepljenih plakata »kuhati na ulju« od Unioreklam, 3. 11. 1934. (600 plakata); GZ NSK, OSG, Dopis Jugoreklam, 2. 11. 1934. (80 plakata).

38 GZ NSK, OSG, Dopis Jugoreklam PHTU, Zagreb, 2. 11. 1934. Dijapozitiv se izradio prema Glumčevu plakatu (za 100 dinara), a za 250 dinara prikazivao u kinu Central tijekom mjesec dana (10. studenoga - 9. prosinca 1934.).

39 Vidi bilj. 30. Građane se nastojalo potaknuti da obave pokusno kuhanje, a pri tome se naglašavalo da kuhanje na ulju sprečava debljanje te predstavlja znatnu uštedu za kućni budžet.

$40 \mathrm{O}$ širini reklamne akcije svjedoči činjenica da je knjiga naručena u nakladi od 5000 primjeraka. GZ NSK, OSG, Dopis Zaklade tiskare Narodnih novina u Zagrebu, 13. 10. 1934. Više o Štefaniji Bernas: SPOMENKA ŠTIMEC, Štefanija Belošević - zagorska učiteljica, Hrvatsko zagorje, 1-2 (2010.), 269-272.

41 Motiv s plakata objavljen je na stražnjim koricama knjige Š. Bernas, a nalazio se i na letcima.

42 Meinlove reklame obilježavao je tradicionalan i opisan crtež koji je pratio tekst, nije se težilo promišljenoj vizualizaciji poruke niti ispreplitanju vizualne i verbalne dimenzije oglasa i ostalih reklamnih materijala. 43 Vidi bilj. 30.

44 Npr. korišteno je na Jesenskom zagrebačkom zboru 1936. Podatak na osnovi fotografije Foto Doneganija u HR-DAZG-251, kut. 178.

45 Glumac je oblikovao naslovne stranice za male brošure (knjižice recepata) u koje su umetani tjedni jelovnici različitih autorica (Štefanije Bernas, Jerice Zemljanove) s odabirom jela pripremljenih na ulju. Isti motiv izlijevanja ulja iskorišten je i za naslovnicu slovenskog prijevoda kuharice Š. Bernas. ŠTEFANIJA BERNAS, Kuhanje na olju, Zagreb, 1938. 46 Više u: LOVORKA MAGAŠ BILANDŽIĆ (bilj. 1), 283-286.
47 LOVORKA MAGAŠ BILANDŽIĆ, Izložba reklame na Zagrebačkom zboru 1934., Radovi Instituta za povijest umjetnosti, 39 (2015.), 183.

48 EMEM NAZOR, Reklama, Zagreb, 1931., 212-213.

49 Primjeri se nalaze u GZ NSK, OSG.

50 Primjeri se nalaze u GZ NSK, OSG.

51 Naziv se prvo mijenja u Tvornica ulja - Crvena zvijezda, Zagreb, a nedugo zatim u Tvornica ulja Zagreb te postaje državno poduzeće. Više o poslijeratnom razvoju u: Tvornica ulja Zagreb 1916-1966 (bilj. 4).

52 Više u: ŽELJKA KOLVESHI, Zvonimir Faist: Diktati vremena - Plakati od kasnih 1930-ih do ranih 1960-ih godina, katalog izložbe, Muzej grada Zagreba, Zagreb, listopad-prosinac 2003., 61, 108. Primjeri tipografskog oglasa (1931.) i Faistova plakata (1960.) namijenjeni oglašavanju Tvornice ulja objavljeni su u: Umjetnost uvjeravanja: oglašavanje u Hrvatskoj 1835-2005., katalog izložbe, (ur.) Feđa Vukić, Hrvatski oglasni zbor, Zagreb, 12. 6.-16. 7. 2006., 246, 257.

\section{REFERENCES}

-, Akcija plinare za racionalno trošenje plina u Zagrebu, Jutarnji list, XXIII /8048 (27 June 1934), 6.

ŠTEFANIJA BERNAS, Kuhanje na olju, Zagreb, 1938.

M. Dt. [MIROSLAVA DESPOT], "Aleksander, Samuel D. (Alexander)", Hrvatski biografski leksikon, Vol. 1, (ed.) Nikica Kolumbić, Jugoslavenski leksikografski zavod, Zagreb, 1983, 71-72.

M. Dt. [MIROSLAVA DESPOT], "Aleksander, Šandor A. (Alexander)", Hrvatski biografski leksikon, Vol. 1, (ed.) Nikica Kolumbić, Jugoslavenski leksikografski zavod, Zagreb, 1983, 72.

STEPHEN FOX, The Mirror Makers: A History of American Advertising and Its Creators, University of Illinois Press, Urbana, Chicago, 1997.

H. K. FRENZEL, Réne Clarke, Gebrauchsgraphik, 10 (1927), 2-10.

RENATA GOTTHARDI ŠKILJAN, Plakat u Hrvatskoj do 1941., exhibition catalogue, Kabinet grafike JAZU, Zagreb, 3 February - 8 March 1972.

PREDRAG HARAMIJA, Majstori hrvatskog plakata: Pavao Gavranić / Sergije Glumac, exhibition catalogue, Kabinet grafike HAZU, Zagreb, 1994.

LADA KAVURIĆ, Hrvatski plakat do 1940., Institut za povijest umjetnosti, NSK, Horetzky, Zagreb, 1999.

VESNA KEDMENEC KRIŽIĆ, Pavao Gavranić: radovi iz Kabineta grafike HAZU, exhibition catalogue, Kabinet grafike HAZU, Zagreb, November-December 2005.

VESNA KEDMENEC KRIŽIĆ, Prvaci hrvatskog plakata: Csikos, Crnčić, Krizman, Babić, exhibition catalogue, Kabinet grafike HAZU, Zagreb, April-May 2011.

ŽELJKA KOLVESHI, Zvonimir Faist: Diktati vremena - Plakati od kasnih 1930-ih do ranih 1960-ih godina, exhibition catalogue, Muzej grada Zagreba, Zagreb, October-December 2003.

JOSO LAKATOŠ, Privredni almanah Jugoslavenskog Lloyda, Jugoslovenska štampa, Zagreb, 1929.

LOVORKA MAGAŠ, Reklamni zavod Imago i komercijalni grafički dizajn u Hrvatskoj 1920-ih, Peristil, 51 (2008), 99-118.

LOVORKA MAGAŠ BILANDŽIĆ, Sergije Glumac - život i djelo, PhD Thesis, Filozofski fakultet Sveučilišta u Zagrebu, Zagreb, 2012.

LOVORKA MAGAŠ BILANDŽIĆ, Izložba reklame na Zagrebačkom zboru 1934., Radovi Instituta za povijest umjetnosti, 39 (2015), 177-188.

IVAN MIRNIK, Obitelj Alexander ili kratka kronika izbrisanog vremena, Radovi Zavoda za hrvatsku povijest, 28 (1995), 96-127.

EMEM NAZOR, Reklama, Zagreb, 1931.

ZDENKA ŠIMONČIĆ-BOBETKO, Industrija Hrvatske od 1918. do 1941. godine, AGM, Zagreb, 2005.

SPOMENKA ŠTIMEC, Štefanija Belošević - zagorska učiteljica, Hrvatsko zagorje, 1-2 (2010), 269-272.

Tvornica ulja Zagreb 1916-1966, Zagreb, 1966. 
Umjetnost uvjeravanja: oglašavanje u Hrvatskoj 1835-2005., exhibition catalogue, (ed.) Feđa Vukić, Hrvatski oglasni zbor, Zagreb, 12 June - 16 July 2006.

FEĐA VUKIĆ, Stoljeće hrvatskog dizajna, Meandar, Zagreb, 1996.

BORIS ZAKOŠEK, Obitelj Aleksander, Vjesnik Državnog arhiva u Rijeci, 43-44 (2002), 121-157.

Zvijezda.hr, URL: http://www.zvijezda.hr/retrospektivna-izlozba-msuzagreb-vremeplov-zvijezdine-proizvode (03/10/16).

SALIH ZVIZDIĆ, Tvornica ulja - Zagreb: 1916-1986, Spektar, Tvornica ulja - Zagreb, Zagreb, 1986.

\author{
ARCHIVAL SOURCES \\ Grafička zbirka Nacionalne i sveučilišne knjižnice, Zagreb, Ostavština \\ Sergija Glumca (GZ NSK, OSG) \\ Državni arhiv u Zagrebu, Fond 109. I. muška realna gimnazija, 1854. \\ -1945., sign. 8 (24162), Urudžbeni zapisnik 1919.-1922., god. \\ 1920., br. 833; HR-DAZG-109, sign. 64 (23023), Glavni katalog \\ $1920 / 21$. \\ Državni arhiv u Zagrebu, Fond 251. Zagrebački zbor 1909.-1945., kut. \\ 172; HR-DAZG-251, kut. 178.
}

Summary

Lovorka Magaš Bilandžić

Sergije Glumac and the Visual Identity of the First Croatian Oil Factory in the 1930s

On the basis of archival records, correspondence and preserved sketches, posters and other material, the paper analyses the broad and intense collaboration of graphic artist and graphic and stage designer Sergije Glumac with the First Croatian Oil Factory (est. 1916) owned by the prominent Jewish family Aleksander. During the 1930s, Glumac designed the Factory's distinct visual identity and coordinated its entire advertising activities - from product placement by means of intense advertising to designing exhibition spaces and organizing displays at important commercial exhibitions (Zagreb Fair, Ljubljana Fair). The modernity and purity of visual expression, message structuring and construction of connotative meanings distinguished his creations from the design which accompanied other oil products (e. g. Riviera, Meinl) advertised in the Kingdom of Yugoslavia during the interwar period. Glumac was familiar with international models (Réne Clarke) and successfully reinterpreted the conventional motifs used in oil-related advertising (e.g. oil pouring). His designs varied from stylized sketches with elements of avant-garde tendencies and existing modern posters to conventional solutions focused on skilful, realistic drawing and accentuated colour. He applied different marketing techniques in the creation of a product's image, emphasized oil quality, its health advantages and good value for money. Glumac's graphic design and his coordination of an intense several-month-long advertising campaign entitled "Cooking with oil" realized in 1934 in various forms (from conventional advertising to cinema ads and personalized approach) bear witness to the broad range of his activities and his significant contribution to Croatian food industry advertising during the interwar period. 